\title{
The use of high-dose azidothymidine in combination with chemotherapy upfront is an effective treatment approach for gamma-herpes virus-related non-Hodgkin's lymphomas
}

\author{
Ulas Darda Bayraktar ${ }^{1}$, Eileen Bernal ${ }^{1}$, Lisa Cabral ${ }^{1}$, William J Harrington Jr. ${ }^{1}$, Dirk P Dittmer ${ }^{2}$, Juan Carlos Ramos ${ }^{1 *}$
}

From $12^{\text {th }}$ International Conference on Malignancies in AIDS and Other Acquired Immunodeficiencies (ICMAOI)

Bethesda, MD, USA. 26-27 April, 2010

\section{Background}

Azidothymidine (AZT), a thymidine analogue, is an excellent substrate for gamma-herpes virus thymidine kinases (TKs). Our group previously demonstrated that AZT alone can inhibit NF- $\kappa \mathrm{B}$ and disrupt EBV latency in primary low-passage Type I latency EBV+ Burkitt lines. The addition of hydroxyurea, which increases the intracellular levels of AZT monophosphate, synergized with AZT in Type III latency EBV+ immunoblastic lymphoma cell lines. The use of AZT in targeting gamma-herpes virus lymphomas is an attractive concept given that this drug is preferentially phosphorylated by EBV and HHV-8 TKs as compared to non-thymidine nucleoside analogues. The drugs methotrexate (MTX) and doxorubicin (DOX) also induce lytic expression of gamma-herpes viruses. MTX inhibits thymidylate synthase, thus blocking de novo synthesis of dTMP and increasing the likelihood of AZT incorporation into DNA. We have found that the combination of high-dose AZT with MTX, used alone or with alternating standard chemotherapy, can result in dramatic

Table 1

\begin{tabular}{|c|c|c|c|c|c|c|c|c|c|c|}
\hline Age & $\begin{array}{l}\text { Lymphoma } \\
\text { type }\end{array}$ & Stage & PS & HIV & CD4 & $\begin{array}{l}\text { Alternating } \\
\text { regimen }\end{array}$ & RT & $\begin{array}{l}\text { Sustained Response } \\
\text { (months) }\end{array}$ & $\begin{array}{l}\text { Progression } \\
\text { (months) }\end{array}$ & $\begin{array}{l}\text { Death } \\
\text { (months) }\end{array}$ \\
\hline 34 & DLBCL & IVB & 3 & + & 4 & - & - & PD & 1.0 & 1.3 \\
\hline 49 & $B L$ & IVB & 2 & + & 91 & $\mathrm{EPOCH}$ & - & CR (50) & - & - \\
\hline 40 & $B \mathrm{~L}$ & $\| A$ & 2 & - & - & hCVAD & + & CR (57) & - & - \\
\hline 51 & DLBCL & IVB & 2 & + & 47 & $\mathrm{EPOCH}$ & - & CR (65) & - & - \\
\hline 40 & $B L$ & IVB & 2 & + & 214 & hCVAD & - & PD & 2.0 & - \\
\hline 34 & PBL & IVB & 2 & + & 16 & - & - & PD & 1.0 & 4.5 \\
\hline 33 & PBL & $\| A$ & 1 & + & 166 & $\mathrm{EPOCH}$ & - & CR (18) & - & - \\
\hline 44 & PBL & IVA & 1 & + & 458 & $\mathrm{EPOCH}$ & - & CR (19) & - & - \\
\hline 52 & PBL & $\| B$ & 1 & + & 57 & $\mathrm{EPOCH}$ & + & CR (20) & - & - \\
\hline 51 & Solid PEL & IVB & 2 & + & 113 & - & - & $C R(31), 2^{\text {nd }} C R(10)$ & After 1st line: 31.1 & - \\
\hline
\end{tabular}

PS: ECOG performance score; RT: radiotherapy; DLBCL: diffuse large B-cell lymphoma; PEL: primary effusion lymphoma; PBL: plasmablastic lymphoma. EPOCH: etoposide, prednisone, vincristine, cyclophosphamide, doxorubicin; hyper CVAD: dexamethasone and fractionated vincristine, doxorubicin cyclophosphamide; CR: complete remission; PR: partial remission; PD: progressive disease.

\footnotetext{
*Correspondence: jramos2@med.miami.edu

'Division of Hematology/Oncology, University of Miami Miller School of

Medicine, Miami, FL, USA

Full list of author information is available at the end of the article
} 
clinical responses and even cures in patients with poor prognosis gamma-herpes virus-related lymphomas.

\section{Materials and methods}

Ten patients with EBV-positive (9 HIV-positive) nonHodgkin's lymphoma (NHL) were treated with first-line MTX (3.0-4.5 g/ $\mathrm{m}^{2}$ IV on day 1) and AZT $1.5 \mathrm{~g}$ IV infusion q12 hours (days 1-4) every 3 weeks or alternated with other chemotherapy regimens, including $\mathrm{EPOCH}$, or hyper cVAD between 2004-2009 at the discretion of the treating physician (Table 1). One patient (solid PEL) received AZT and MTX initially, and upon relapse 31 months later received DOX $20 \mathrm{mg} / \mathrm{m}^{2}$ (Day 1), MTX 5 $\mathrm{g} / \mathrm{m}^{2}$ (Day 2), and AZT $750 \mathrm{mg}$ twice daily with hydroxyurea $1 \mathrm{~g}$ daily (Days 2-5) under our new clinical trial.

\section{Results}

Clinical characteristics, response, and survival data of patients are summarized in Table 1. All patients were treated with high-dose AZT and MTX. Three patients with plasmablastic lymphoma (PBL) and 1 patient with $\mathrm{BL}$ also received alternating $\mathrm{EPOCH} ; 2 \mathrm{BL}$ patients received alternating hCVAD. Seven patients achieved CR. Two patients developed neutropenic fever. Median PFS in this cohort of patients has not been reached. Median OS was 31 months (95\% CI: 0.0-84.8).

\section{Conclusions}

The combination of high-dose MTX/AZT is a promising and tolerable treatment for gamma-herpes virusrelated lymphomas. A Phase II clinical trial with low-dose doxorubicin, MTX, AZT, and hydroxyurea for relapse EBV+ NHL is currently recruiting participants. Interim results and supporting laboratory data for using this gamma-herpes virus lytic approach will be presented at the meeting.

\section{Acknowledgements}

This article has been published as part of Infectious Agents and Cancer Volume 5 Supplement 1, 2010: Proceedings of the $12^{\text {th }}$ International Conference on Malignancies in AIDS and Other Acquired Immunodeficiencies (ICMAOI). The full contents of the supplement are available online at http://www.biomedcentral.com/1750-9378/5?issue=S1.

\section{Author details}

'Division of Hematology/Oncology, University of Miami Miller School of Medicine, Miami, FL, USA. ${ }^{2}$ Department of Microbiology and Immunology, University of North Carolina at Chapel Hill, Chapel Hill, NC, USA.

Published: 11 October 2010

\section{doi:10.1186/1750-9378-5-S1-A81}

Cite this article as: Bayraktar et al:: The use of high-dose azidothymidine in combination with chemotherapy upfront is an effective treatment approach for gamma-herpes virus-related non-Hodgkin's lymphomas. Infectious Agents and Cancer 2010 5(Suppl 1):A81.

\section{Submit your next manuscript to BioMed Central} and take full advantage of:

- Convenient online submission

- Thorough peer review

- No space constraints or color figure charges

- Immediate publication on acceptance

- Inclusion in PubMed, CAS, Scopus and Google Scholar

- Research which is freely available for redistribution 